DOI https://doi.org/10.18551/rjoas.2018-01.06

\title{
PLANNING ANALYSIS OF LAND AND BUILDING TAX OF RURAL AND URBAN SECTORS AFTER BEING LOCALLY TAXED
}

\author{
Yulianti Laely*, Herwanti Titiek, Hermanto \\ Master Program of Accounting, University of Mataram, Indonesia \\ ${ }^{*}$ E-mail: laelyaan@gmail.com
}

\begin{abstract}
This study aims to analyze the land and building tax planning of rural and urban sectors implemented by the Regional Revenue Office of Sumbawa Regency and to examine deeper the planning problems arising from the Land and Building Tax of Rural and Urban sector, hereinafter referred to as PBB-PP after prevailing the Law of Regional Tax and Regional Retribution \#28 of 2009 (Law of PDRB). Data analysis is conducted by using Miles and Hubberman models. The results indicate that there are several factors that have not been optimal in land and building tax of rural and urban sector planning. These factors are human resources, administrative completeness, local policy, control and accountability.
\end{abstract}

\section{KEY WORDS}

Land, building, tax, planning, law, policy, supervision.

The era of regional autonomy nowadays provides an opportunity for a change in the national development paradigm from the growth paradigm to the equitable and equal distribution of development paradigm. This paradigm change, among others, is realized through the policy of regional autonomy and the balance of central and regional finances as regulated in a package of Laws namely Law Number 22 of 1999 on Regional Government and Law Number 25 of 1999 on Financial Balance between Central Government and Local government.

The policy of granting broad, real, and responsible regional autonomy and decentralization is a strategic step in two respects. First, regional autonomy and decentralization are the answers to the local problems of Indonesia in the form of the nation disintegration threat, poverty, development inequality, community life low quality, and human resource development (HR) problem. Second, regional autonomy and fiscal decentralization are the strategic steps of Indonesia to welcome the era of economic globalization by strengthening the regional economic base.

The autonomy mandated to districts and municipalities is performed by granting broad, real, and responsible proportionally, meaning that, the assignation of responsibilities will be followed by equitable sharing arrangements and utilization and national resources, central and regional financial balances. Fundamentals of the regional autonomy laws are the strong efforts to encourage community empowerment, initiative and creativity development, community participation, and roles and functions development of the Regional House of Representatives (DPRD). This law provides full autonomy to the districts and municipalities to establish and to implement policies according to community initiatives and aspirations. It means that the regions have been given full authority to plan, to implement, to supervise, to control, and to evaluate the policies of the region. With the growing participation of the people, decentralization will then affect the quality of other governmental components. One of them is related to the shift of government orientation, from comment and control to be more oriented on public demands and needs. This kind of orientation will afterwards become the basis for the implementation of the government's role as a stimulator, a facilitator, a coordinator and an entrepreneur in the development process.

One of the broad, real, and responsible authority given to the region is through Law Number 28 of 2009 as the substitute of Law Number 18 of 1997 and Law Number 34 of 2000 regarding Regional Tax and Retribution (hereinafter referred to as the PDRD Law), the region has been given the authority to levy taxes (taxing power). Since officially applied on 
January 1, 2010, local governments must prepare themselves to face the challenge of managing tax items which are previously administered by the central government to be handed over to the regions.

Law Number 28 of 2009 states that there are several types of taxes collected by the Regency/City. Regency tax types consist of: Hotel Tax; Restaurant tax; Entertainment Tax; Advertisement tax; Street Lighting tax; Non-metallic and rock mineral taxes; Parking Tax; Groundwater Tax; Swallow's Nest Tax; Land and Rural and Urban Building Tax; and Land and Building Title Transfer Duty. Especially on the division of Land and Building Tax in Urban and Rural Sector or it is more known as PBB-PP.

Land and Building Tax of Rural and Urban sector (PPB-PP) which is previously a central tax, transferred into local taxes, with various considerations. First, conceptually, Land and Building Tax of Rural and Urban sector (PBB-PP) can be collected by the region because it is more local, visible, immobile tax object, and there is a close relationship between the taxpayer and the beneficiary of the tax. Second, the transfer of Land and Building Tax of Rural and Urban sector (PBB-PP) to the regions is expected to increase Original Local Government Revenue (PAD) and to improve the structure of Local Government Budget (APBD). Third, the transfer of Land and Building Tax of Rural and Urban sector (PBB-PP) to the regions can improve services to the community, and can improve the aspects of transparency and accountability in its management. Fourth, based on practices in many countries, Land and Building Tax of Rural and Urban sector (PBB-PP) is included in the type of local tax (DJPK, 2014).

There are at least four basic changes set out in the law. First, changing the local taxes and retribution administration from open-list system to closed-list system. Second, granting greater authority to the regions through the expansion of the local tax base and regional retribution, the addition of new types of taxes that will be collected by the regions, and the provision of discretion to the regions to set tariffs within the prescribed maximum and minimum tariff limits. Third, improving the management system of local taxes and regional retribution through provincial tax revenue sharing policy to regency/city and earmarking policy for certain types of local taxes. Fourth, improving the effectiveness of local levies policy by changing the mechanism of supervision from the repressive system to preventive and corrective systems.

The local government of Sumbawa Regency is expected to be able to manage the PPB-PP optimally, so that the local revenue from the tax sector can be increased and can accelerate the regional financial independence in order to increase the fiscal capacity or ability to finance regional development. The local government of Sumbawa Regency should be fully aware that this Land and Building Tax (PBB) changing agenda is a big job, in addition to confronting some obstacles, it also needs time and careful planning to ensure that the process is working and is delivering optimal results.

Planning is an important step in local financial management; planning is the first step that must be done by the local government of Sumbawa Regency to look forward related to what actions should be taken to achieve certain goals (Mardiasmo, 2009). Government activities will be well implemented if all planning phases are realized consistently. Land and Building Tax of Rural and Urban sector (PBB-PP) should be a primadonna of the Sumbawa Regency's revenue, given the relatively large and fixed characteristics of the object with a value that always rises from year to year. However, the great potential needs a good and a reliable management system. Good management starts from good planning. The benefit of a plan is the direction and objective that must be achieved from time to time and as a reference in the operation of the relevant agencies. For the agencies given the tasks and functions of managing local revenue, revenue planning is a target that is usually presented quantitatively and expressed in unit of money prepared for a certain period. Here is a plan set by the Sumbawa Regency government for Land and Urban and Rural Building Tax as seen in the following table 1.

From table 1, the target of Land and Building Tax of Rural and Urban sector (PBB-PP) revenue in 2014 is the target set based on the Notification of Tax Due (SPPT) amount and value data as stated in the application of Tax Object Management Information System 
(SISMIOP) submitted by the Directorate General of Tax, Tax Office (KPP) Pratama of Sumbawa in the early period of the transfer of Land and Building Tax of Rural and Urban sector (PBB-PP) to local taxes.

Table 1 - Target and Realization of PBB-PP Revenue of Sumbawa Regency after Becoming a Local Tax

\begin{tabular}{|c|c|c|c|c|}
\hline Year & Description & Target & Realization & $\%$ \\
\hline 2014 & PBB-PP Revenue & 4.000 .000 .000 & 3.952 .952 .553 & 98,82 \\
\hline 2015 & PBB-PP Revenue & 6.000 .000 .000 & 3.989 .215 .419 & 66,49 \\
\hline 2016 & PBB-PP Revenue & 6.000 .000 .000 & 3.952 .952 .553 & 65,88 \\
\hline 2017 & PBB-PP Revenue & 6.300 .000 .000 & 4.689 .254 .916 & 74,43 \\
\hline
\end{tabular}

Source: processed secondary data (2017).

The planning improvement (target) drastically occurs in 2015 by $50 \%$ from the previous year and in 2017, the target increase is only 5\% from 2016, it is an interesting phenomenon for researchers to analyze and understand how the Land and Building Tax of Rural and Urban sector (PBB-PP) revenue planning process, why the planning made then stated in the budget tends to do not have any increase, and has the planning process already illustrated the potential of actual revenue.

\section{METHODS OF RESEARCH}

The main objective of this research is to analyze, to understand, and to examine more deeply and more thoroughly the planning phenomenon of Land and Building Tax in Urban and Rural Sector (PBB-PP), hence, in this research, the approach used is qualitative approach. The consideration of the researcher using qualitative approach is because qualitative research is a research that attempts to understand phenomenon in its setting and its natural context (not in the laboratory) where the researcher does not try to manipulate the observed phenomenon (Patton, 2002). Creswell (2010) states that qualitative research is a method to explore and to understand the meaning that by some individuals or groups of people are considered coming from social problems.

Qualitative research considers everything that involves human beings to be complex and to be multidimensional, especially if it involves a group of people and their interactions, the complexity will be very difficult to be measured by statistical figures (Sarosa, 2012). Qualitative research seeks to understand the complexity of the researched phenomenon in which the researcher attempts to interpret a phenomenon and to understand a phenomenon from the point of view of the actor in it.

The paradigm used in this research is interpretive paradigm. The tradition of interpretivism emphasizes the effort of constructing and interpreting the actions of the people, both through their prior knowledge and as reflected through their experience (actors) involved in social action (Chua, 1988 in Djamhuri, 2011). Finding the hidden meanings behind social actions as understood by principals (the researched actors) through a good understanding effort is the goal of the interpretive sociology expressed by Djamhuri (2011).

Burrell and Morgan (1979: 20) describe the interpretive nature as a paradigm that has characteristics to understand and to explain the social world that cannot be separated from personal experience directly involved in a social process. The social role of society, the research bound to the norms, certain rules and beliefs, and the views and attitudes of informants (Muhadjir 2000: 12). The present research is conducted by interviewing several informants who have individual experience and are influenced by the research environment (Creswell 2015: 79).

The research method used in this research is by case study approach. According to Yin (2015), case study is an empirical inquiry that investigates phenomena in a real-life context, when the boundaries between phenomena and the context are not visibly apparent, and where multiple sources of evidence are used. The phenomenon and context of the Land and Building Tax of Rural and Urban sector (PBB-PP) planning in Sumbawa Regency is not 
clearly visible, thus, various sources of evidence is utilized to analyze it. Case study is a research strategy in which the researcher carefully investigates a program, event, activity, process or group of individuals (Creswell, 2010).

Based on the definitions and the objectives in this study, the researcher refers to choose a single case study (single case design) with one unit of analysis (holistic). The unit of analysis is the case itself (Yin, 2015). This research is conducted in 2017 at Sumbawa Regency Revenue Agency. Sumbawa Regency Revenue Agency is an institution that is authorized in performing the levy and the management of local taxes including Land and Rural and Urban Building Tax in Sumbawa Regency.

\section{RESULTS AND DISCUSSION}

Land and Building Tax in Urban and Rural Sector (PBB-PP) depend on the fiscal potential of the producing region. The fiscal potential is all land and building that is taxable according to the Act. To be able to rely on Land and Building Tax of Rural and Urban sector (PBB-PP) revenue as one of the sources of regional revenue, a thorough approach is needed both to the Taxpayer and to the tax/fiscal officer since the object and subject of Land and Building Tax of Rural and Urban sector (PBB-PP) is very big and wide. This automatically needs the fiscal ability from planning, revenue, to operation.

The arrangement of Land and Building Tax of Rural and Urban sector (PBB-PP) revenue plan should be done well. The preparation of a realistic revenue plan will lead to actual performance. The benefit of a plan is the direction and objective that must be achieved from time to time and as a reference in the organization's operations concerned. The benefit of planning as an operational reference requires the fiscal official to work professionally, including the model determination of the Land and Building Tax of Rural and Urban sector (PBB-PP) revenue prediction. Until nowadays, there is no standard model to determine the Land and Building Tax of Rural and Urban sector (PBB-PP) revenue plan/ The determination of the revenue plan should consider the variables of revenue such as economic growth (GDRP), ability to pay, principal provisions, and arrears in each Land and Building Tax (PBB) service office (Nasucha 1995: 145). According to the General Director of Regional Financial Balance, Land and Building Tax of Rural and Urban sector (PBB-PP) revenue planning starts from the determination of the Land and Building Tax of Rural and Urban sector (PBB-PP) revenue-forecasting model, the calculation and stipulation of Land and Building Tax of Rural and Urban sector (PBB-PP) revenue target to the preparation of work programs to achieve the established targets and anticipatory steps if in the current period, certain targets cannot be reached.

In addition, planning (target) and achievement of targets (realization) are closely related to the performance of an organization (DGPK, 2014). In setting targets, the question of whether it reflects the true potential becomes an important part of the planning section of the regional revenue management organization to know more realistic Land and Building Tax of Rural and Urban sector (PBB-PP) revenue. If it is not done, then the determination of the revenue plan undertaken can be underestimated so as if the target is reached and describes the performance of the management of the Land and Building Tax (PBB) or otherwise.

There are 2 (two) methods of Target Determination of Tax Revenue used by Local Government, which are: a. Top Down Method, the top down target of Land and Building Tax (PBB) revenues is determined from the target area in advance which refers to the Compilation List of Tax Assessment (DHKP) in the previous year, then it is broken down into the target revenue per district. When discussed about revenue for each sub-district in the district level, by taking into account the amount of the potential revenue for each subdistrict/village areas such as the Sales Value of Taxable Object (NJOP). In determining the amount of Land and Building Tax of Rural and Urban sector (PBB-PP) revenue plans, the sub-districts are based on the number of Notification of Tax Due (SPPT); $b$. The Bottom Up Method, the local government is more instrumental in terms of giving initial ideas to evaluate the programs that have been implemented while the of the Regional House of Representatives (DPRD) as a facilitator in a course of the program. Regional Revenue Office 
(Bapenda) makes an analysis of the potential of several sectors of tax revenue. It is done by creating a targeting simulation by looking at trends or fluctuations or variations in Land and Building Tax of Rural and Urban sector (PBB-PP) revenue data from time to time.

Determination of Target Tax Revenue can also be done based on Planning Theory. In tax revenue planning, there are three approaches called (1) macro, (2) micro, and (3) incremental. The incremental approach is more practical and more pragmatic to be applied for local tax revenue planning. The method used in this incremental approach is done through calculating the realization of previous year's revenue with adjustments to economic growth and inflation rate. Adjustment can also be made to other variables such as interest, price, and oil and gas production, GDRP (Gross Domestic Regional Product), rupiah exchange rate on dollar, and other factors. On the other hand, the tax base variable pattern can be used as an option in the projection of tax revenues by taking into account the factors that influence, among others: macroeconomic condition, purchasing power, service provision, public policy, and population mobilization.

In determining the projection of local tax revenues, it is necessary to determine the classification of revenue potential for each type of local tax. The classification of potential tax revenues can be classified into: a. Prime Revenue; Regional taxes are included into prime revenue classification if the additional ratio (growth) is greater than or equal to one. $b$. Potential Revenue; Regional taxes are included into potential revenue classification if the additional ratio (growth) is less than or equal to one and the ratio of the proportion or contribution to the average total tax revenue or user charges is greater than or equal to one. c. Developing; Regional taxes belong to the developing classification if the additional ratio (growth) is greater than or equal to one and the ratio of the proportion or contribution to the average total local tax revenue is greater than or equal to one. $d$. Underdeveloped; Regional taxes are included into underdeveloped classification if the additional ratio (growth) or contribution to the average total local tax revenue are either smaller or equal to one.

In addition, to determine the potential of local tax revenues into the above classification, two main indicators are needed: a. Proportion Ratio; Proportion ratio determination is done by comparing the realization of revenue of certain types of local taxes and the average revenue of local taxes. The local taxes are mostly from the calculation of the total amount of local tax revenue divided by the number of types of local taxes. $b$. Additional Ratio; Determination of additional ratio is done by comparing the growth of certain tax types and the growth of total taxes and levies.

During this time, the targeting of local tax revenues has been based on incremental rules (a certain percentage is increased from last year) as conducted by the Sumbawa Regency Revenue Agency, not based on potential revenue. The potential of local revenue for each type of local tax has not been calculated thoroughly. The measurement of work performance in local tax revenue is still based on the collection ratio, which is the ratio used to measure the percentage of realization of local tax revenue from the target of local tax revenue and not the size of the coverage ratio, which includes the ratio of proportion and growth ratio. While the action plan of increasing regional revenue is more considered as a regular activity of levying organizations.

Estimating Growth with Extrapolation Technique; this is one of the simplest techniques for assessing growth, i.e. by doing assessment using two selected data to represent the data spread to be developed by the assessor. Therefore, the extrapolation technique assumes that the increment value of the dependent variable for each unit of change of the independent variable value is linear. Given that the technique is so simple, this technique can produce low accuracy value estimates. However, under certain conditions (limited technical facilities, or limited data available as a basis for assessment), extrapolation technique can be helpful to see a rough idea.

It cannot be denied that the amount of revenue or achievement of revenue targets is influenced by the level of public awareness in paying taxes. Not only the type of tax paid by the taxpayer, but also the type of tax that is paid on the basis of the provisions as well like Land and Building Tax of Rural and Urban sector (PBB-PP). The followings are some of the things that can affect the amount of Land and Building Tax of Rural and Urban sector (PBB- 
$\mathrm{PP})$ revenue in the region so that it will greatly affect the next planning process: first, the awareness of the people who are still low in paying taxes. The tendency of our society in general is to minimize the cost of spending including the expenditure to pay taxes, so it is frequently to see the new people will pay taxes when it is billed or when the tax obligations are associated with government services. Second, the public has not understood the tax functions yet; this is a factor inhibiting their own so they are reluctant to fulfill its obligations. This reluctance is caused more by the fact that the public has not understood the importance of the tax function yet, especially if the people do not or have not felt directly the result of the taxes they paid. Inequality of development perceived by the community in the village makes its own resistance in fulfilling the tax obligations. Third, there is no clear legal law related to Standard Operational Procedure (SOP) of Land and Building Tax of Rural and Urban sector (PBB-PP) so that there is a mistake in the document of determination. The occurrence of errors or mistakes in the determination of taxes becomes the next inhibiting factor. Although legally, such errors can be corrected through a process of correction or process of objection by the taxpayer, but it is difficult for some people to do due to lack of socialization on procedures for the management by the Regional Government, in this case, the Regional Revenue Agency. Fourth, the tariff is too much. Land and Tax Building (PBB) tariffs that are too much cause the burden of taxes to be borne by the community becomes larger, especially if the tariff is caused by the increase in tariffs from previous years. The experts argue that not always the increase in tax rates lead to an increase in revenue. It may happen that the taxpayer will make various efforts to reduce the tax burden or some business actors must roll out and stop his business because the tax burden is too much; if so, then it can be ascertained that the amount of tax objects will be reduced which ultimately leads to the decrease in revenue. Fifth, the lack of strict implementation of legal sanctions on local taxes. Land and Building Tax of Rural and Urban sector (PBB-PP) is basically a relatively cheap local tax for some people, only the number of objects that are relatively much and spread throughout the region. This condition causes the difficulty of active billing actions if certain taxpayers do not pay. Inevitably, it is possible to do but with the consequence that the cost to do needs a relatively larger billing. This condition also occurs in the imposition of legal sanctions to the taxpayer, for example, will the billing be active until the letter of force or confiscation on the Land and Building Tax of Rural and Urban sector (PBB-PP) obligation by a taxpayer who does not also pay the Land and Building Tax of Rural and Urban sector (PBB-PP) of fifty thousand dollars? Social sanctions would be more effective to enforce, where the Land and Building Tax of Rural and Urban sector (PBB-PP) pay-as-tax evidence is a prerequisite that should be attached in every governmental affair starting from the District/Village level. Sixth, the lack of facilities and infrastructure. It is related to the ease of making payment or filing services to the tax authorities either correction services, deductions or objections to the determined tax. The lack of facilities or the difficulty of the procedure causes people to be reluctant to process and consequently they do not fulfill their obligations.

\section{CONCLUSION}

The regional finance management is the whole activity that covers planning, implementation, administration, reporting, accountability, and supervision of regional finances. Planning phase is the first step that must be taken by the manager of local finance both local revenue manager and regional expenditure managers. Realistic planning will lead to real performance because planning is an operational reference for the tax authorities to work professionally. The arrangement of Land and Building Tax of Rural and Urban sector (PBB-PP) revenue plan is a quantitatively presented target and is usually expressed in unit of money prepared for a specified period of time.

There are several ways used by the local government of Sumbawa Regency, in this case, the Regional Revenue Agency as the organization of receiving revenue in planning and setting the target of Land and Building Tax of Rural and Urban sector (PBB-PP) revenue which are: 1. Targeting using top down and bottom up methods; 2 . Determination of tax 
revenue target based on planning theory with incremental approach (a certain percentage is increased from last year).

From the factors that inhibit the achievement of Land and Building Tax of Rural and Urban sector (PBB-PP) revenue target above, the efforts can be made to increase Land and Building Tax of Rural and Urban sector (PBB-PP) revenue. In general, these efforts can be done through two ways which are by intensification and extensification. a. The intensification method is to effectively and efficiently collect the existing Land and Building Tax of Rural and Urban sector (PBB-PP) objects and subjects such as calculating potential, counseling, supervision, and service enhancement and involving elements of government until the village level or Neighborhood/Hamlet level if necessary. b. The extensification method is to make efforts to collect new taxpayers through new registration. It is not impossible that the development of the region causes a change in the condition of the tax object so that there is an increase in the Selling Value of Tax Objects. These conditions should be understood by tax officials by proactively re-registering and/or collecting new data for revenue to increase. In conjunction with the above planning theory, if the Land and Building Tax of Rural and Urban sector (PBB-PP) in a region is included in the prime category, then the tax policy adopted in the previous year (including when the Land and Building Tax of Rural and Urban sector (PBB-PP) is managed by Tax Office (KPP)) can still be used by maintaining the growth rate and its contribution to the regional revenue. If it is included into potential revenue, then the effort that needs to be done is to intensify the collection of existing objects so that there is a growth of revenue. For the developing classification, the improvement efforts are done by digging up new sources by way of collecting new data or by adjusting the Sales Value of Taxable Object (NJOP) that has been too long unadjusted. If the Land and Building Tax of Rural and Urban sector (PBB-PP) is in the backward classification, then the improvement effort is done by re-registering, restructuring the tariff policy and re-adjusting the Sales Value of Taxable Object (NJOP). Undeniably, these things are coupled with the ability of people to pay taxes.

\section{REFERENCES}

1. Burrell, G., \& Morgan, G. (2017). Sociological paradigms and organisational analysis: Elements of the sociology of corporate life. Routledge.

2. Creswell, J. W. (2015). Penelitian Kualitatif \& Desain Riset Memilih Di Antara Lima Pendekatan. Edisi Ke-3. Pustaka Pelajar. Yogyakarta.

3. Creswell, J. W. (2010). Research Design Pendekatan Kualitatif, Kuantitatif, dan Mixed. Pustaka Pelajar. Yogyakarta.

4. Djamhuri, A. (2011). “ IImu Pengetahuan Sosial Dan Berbagai Paradigma Dalam Kajian Akuntansi.” Jurnal Akuntansi Multiparadigma,Vol. 2, No.1, hlm 147-185.

5. Lubis, I. (2010). Menggali Potensi Pajak Perusahaan dan Bisnis dengan Pelaksanaan Hukum. PT. Elex Media Komputindo Gramedia. Jakarta.

6. Mardiasmo. (2016). Perpajakan Edisi Terbaru 2016. Andi. Jakarta.

7. Miles, M.B. \& Huberman, A.M. 1992. Analisis Data Kualitatif. Universitas Indonesia (UIPress). Jakarta.

8. Moleong, L.J. (2005). Metodologi Penelitian Kualitatif. PT. Remaja Rosdakarya. Bandung

9. Muhadjir, N. (2000). Metodologi Penelitian Kualitatif. Rake Sarasin. Yogyakarta.

10. Patton, M. Q. (1980). Qualitative Evaluation Methods. Sage Publication. Beverly Hills. California.

11. Sarosa, S. (2012). Penelitian Kualitatif. Indeks. Jakarta Barat.

12. Yin, R.K. (2015). Studi Kasus Desain dan Metode. Rajawali Pers. Jakarta.

13. Undang-undang Nomor 22 Tahun 1999 tentang Pemerintahan Daerah

14. Undang-undang Nomor 25 Tahun 1999 tentang Perimbangan Keuangan antara Pemerintah Pusat dan Pemerintah Daerah.

15. Undang-Undang Nomor 34 Tahun 2000 tentang Pajak Daerah dan Retribusi Daerah.

16. Undang Undang No. 28 Tahun 2009 tentang Pajak Daerah dan Retribusi Daerah. 